\title{
A study of the TNF/LTA/LTB locus and susceptibility to severe malaria in highland papuan children and adults
}

Louise M Randall ${ }^{1,2}$, Enny Kenangalem ${ }^{3}$, Daniel A Lampah ${ }^{3}$, Emiliana Tjitra ${ }^{4}$, Esther D Mwaikambo ${ }^{5}$, Tjandra Handojo ${ }^{3}$, Kim A Piera ${ }^{6}$, Zhen Z Zhao ${ }^{1}$, Fabian de Labastida Rivera', Yonghong Zhou', Karli M McSweeney ${ }^{1}$, Lien Le ${ }^{1}$, Fiona H Amante', Ashraful Haque ${ }^{1}$, Amanda C Stanley ${ }^{1}$, Tonia Woodberry ${ }^{6}$, Ervi Salwati ${ }^{4}$, Donald L Granger ${ }^{7}$, Maurine R Hobbs ${ }^{7}$, Ric N Price ${ }^{6,8,9}$, J Brice Weinberg ${ }^{10}$, Grant W Montgomery ${ }^{1}$, Nicholas M Anstey ${ }^{6,9}$, Christian R Engwerda ${ }^{\text {* }}$

\begin{abstract}
Background: Severe malaria (SM) syndromes caused by Plasmodium falciparum infection result in major morbidity and mortality each year. However, only a fraction of P. falciparum infections develop into SM, implicating host genetic factors as important determinants of disease outcome. Previous studies indicate that tumour necrosis factor (TNF) and lymphotoxin alpha (LT $\alpha)$ may be important for the development of cerebral malaria (CM) and other SM syndromes.
\end{abstract}

Methods: An extensive analysis was conducted of single nucleotide polymorphisms (SNPs) in the TNF, LTA and LTB genes in highland Papuan children and adults, a population historically unexposed to malaria that has migrated to a malaria endemic region. Generated P-values for SNPs spanning the LTATNF/LTB locus were corrected for multiple testing of all the SNPs and haplotype blocks within the region tested through 10,000 permutations. A global Pvalue of $<0.05$ was considered statistically significant.

Results: No associations between SNPs in the TNF/LTA/LTB locus and susceptibility to SM in highland Papuan children and adults were found.

Conclusions: These results support the notion that unique selective pressure on the TNF/LTAVLTB locus in different populations has influenced the contribution of the gene products from this region to SM susceptibility.

\section{Background}

Severe malaria (SM) caused by Plasmodium falciparum results in more than a million deaths each year $[1,2]$. It is a collection of syndromes that includes cerebral malaria (CM), severe malaria anaemia (SMA), acute respiratory distress syndrome (ARDS), hyperparasitaemia, hypoglycaemia, black water fever, metabolic acidosis, jaundice and renal failure [1]. The reasons why some individuals develop severe complications of malaria, whereas others do not, are still unclear. However, the virulence of the parasite strain causing malaria,

\footnotetext{
* Correspondence: chrisE@qimr.edu.au

'Queensland Institute of Medical Research and Australian Centre for Vaccine Development, 300 Herston Road, Herston, QLD 4006, Australia Full list of author information is available at the end of the article
}

as well as the age and genetic background of the infected individual are likely to influence disease outcome.

Plasmodium falciparum and humans have had intense interactions for at least 6,000 years and it is thought that malaria has imposed a large selective pressure on the human genome $[3,4]$. Evidence from both an experimental cerebral malaria (ECM) model [5], as well as from SM patients [6-8], have identified TNF as an important pro-inflammatory cytokine for the control of infection, and also a strong association with the development of pathology. Single nucleotide polymorphisms (SNPs) within the gene encoding TNF (TNF) have been associated with severe outcomes following Plasmodium infection in a number of populations in Africa, Asia and 
the Pacific region [9-13]. In particular, a SNP in the promoter region of $T N F$ at 308 nucleotide base pairs upstream of the transcription start site $(-308 / 376 T N F)$ has been reported to confer a greater risk of severe neurological sequelae or death due to $\mathrm{CM}$ in the Gambia [14]. This variant was found to be a stronger transcriptional activator than the common allele in some in vitro studies [15], but not others [16]. More recent studies examining the MHC class III region, which includes $T N F$ as well as the genes encoding the closely related $\mathrm{LT} \alpha(L T A)$ and LT $\beta(L T B)$, suggest that positive associations between disease and $T N F$ alleles could in fact be due to real disease alleles in neighbouring genes [17]. One such study observed that when specific SNPs were present in TNF, in combination with specific SNPs in LTA, LTA transcription rather than TNF transcription was modulated by changing the way RNA polymerase specifically bound to the LTA promoter [18]. Importantly, LT $\alpha$, not TNF, has been shown to be a critical factor in the development of experimental cerebral malaria in C57BL/6 mice [19], identifying LTA along with $T N F$ as a candidate susceptibility gene.

Recently, a genome wide association study involving 3 African populations from The Gambia, Kenya and Malawi, investigated potential associations between SM and 8 SNPs spanning the LTA/TNF locus [20]. An association was found between $T N F-238 \mathrm{~A}$ allele and SM in samples from The Gambia only, and not for any other SNP tested in any of the populations examined [20]. These findings suggested different selective pressures in the LTA/TNF locus in different populations, as well as highlighting the need for more-detailed mapping of polymorphisms across this locus to identify causal SNPs associated with SM susceptibility [20]. Here, an extensive analysis was conducted of 35 SNP's found in the $L T A / T N F / L T B$ gene locus in adults and children of highland Papuan origin, a population not historically exposed to malaria transmission prior to the $1970 \mathrm{~s}$, but who during the study period had been exposed to malaria following migration to the lowland region of Papua.

\section{Methods}

\section{Study participants and sample preparation}

Characteristics of the study participants upon admission to hospital and controls, including population structure, have been described in Table 1 and the methods section of a recent publication [21]. No corrections were required. Highland Papuan patients with SM and asymptomatic malaria-exposed controls were recruited in a case-control study in Timika, a lowland region of Papua, Indonesia. Genotypes significantly associated with SM in highland Papuans, were also examined in a Tanzanian case-control study comprising children with
Table 1 The SNP set used to investigate the LTA/TNF/LTB locus

\begin{tabular}{|c|c|c|c|c|c|}
\hline $\begin{array}{l}\text { Map } \\
\text { Number }\end{array}$ & db SNP rs & $\begin{array}{c}\text { SNP } \\
\text { Location }\end{array}$ & Gene & Role & Polymorphic \\
\hline 1 & rs2857602 & chr6:31641357 & LTA & Promoter & Yes \\
\hline 2 & rs2844486 & chr6:31641849 & LTA & Promoter & No \\
\hline 3 & rs3131637 & chr6:31643053 & LTA & Promoter & Yes \\
\hline 4 & rs2844484 & chr6:31644203 & LTA & Promoter & Yes \\
\hline 5 & rs2844483 & chr6:31644775 & LTA & Promoter & Yes \\
\hline 6 & rs2009658 & chr6:31646223 & LTA & Promoter & Yes \\
\hline 7 & rs4647191 & chr6:31646617 & LTA & Promoter & No \\
\hline 8 & rs2844482 & chr6:31647746 & LTA & Promoter & Yes \\
\hline 9 & rs2071590 & chr6:31647747 & LTA & Promoter & Yes \\
\hline 10 & rs1800683 & chr6:31648050 & LTA & Promoter & Yes \\
\hline 11 & rs2239704 & chr6:31648120 & LTA & Exon & Yes \\
\hline 12 & rs909253 & chr6:31648292 & LTA & $\begin{array}{c}\text { Intron } \\
\text { (boundary) }\end{array}$ & Yes \\
\hline 13 & rs2857713 & chr6:31648535 & LTA & $\begin{array}{c}\text { Coding } \\
\text { exon }\end{array}$ & Yes \\
\hline 14 & rs3093543 & chr6:31648736 & LTA & $\begin{array}{l}\text { Coding } \\
\text { exon }\end{array}$ & No \\
\hline 15 & rs1041981 & chr6:31648763 & LTA & $\begin{array}{l}\text { Coding } \\
\text { exon }\end{array}$ & Yes \\
\hline 16 & rs1799964 & chr6:31650287 & LTA & 3' UTR & Yes \\
\hline 17 & rs1799724 & chr6:31650461 & LTA & 3' UTR & Yes \\
\hline 18 & rs1800750 & chr6:31650942 & TNF & Promoter & No \\
\hline 19 & rs1800629 & chr6:31651010 & TNF & Promoter & No \\
\hline 20 & rs361525 & chr6:31651080 & TNF & Promoter & No \\
\hline 21 & rs3179060 & chr6:31651651 & TNF & $\begin{array}{l}\text { Coding } \\
\text { exon }\end{array}$ & No \\
\hline 22 & rs3093661 & chr6:31651737 & TNF & $\begin{array}{c}\text { Intron } \\
\text { (boundary) }\end{array}$ & No \\
\hline 23 & rs1800610 & chr6:31651806 & TNF & Intron & Yes \\
\hline 24 & rs3093662 & chr6:31652168 & TNF & Intron & No \\
\hline 25 & rs4645843 & chr6:31652541 & TNF & $\begin{array}{l}\text { Coding } \\
\text { exon }\end{array}$ & No \\
\hline 26 & rs1800620 & chr6:31652570 & TNF & $\begin{array}{c}\text { Intron } \\
\text { (boundary) }\end{array}$ & No \\
\hline 27 & rs3093664 & chr6:31652621 & TNF & $\begin{array}{c}\text { Intron } \\
\text { (boundary) }\end{array}$ & No \\
\hline 28 & rs1800618 & chr6:31652897 & TNF & $\begin{array}{l}\text { Coding } \\
\text { exon }\end{array}$ & No \\
\hline 29 & rs11574936 & chr6:31653172 & TNF & $\begin{array}{l}\text { Coding } \\
\text { exon }\end{array}$ & No \\
\hline 30 & rs3093668 & chr6:31654474 & TNF & 3' UTR & No \\
\hline 31 & rs3091257 & chr6:31654829 & TNF & 3' UTR & Yes \\
\hline 32 & rs769178 & chr6:31655493 & LTB & $3^{\prime}$ UTR & Yes \\
\hline 33 & rs769177 & chr6:31655590 & LTB & 3' UTR & Yes \\
\hline 34 & rs2229699 & chr6:31656835 & LTB & Exon & No \\
\hline 35 & rs1052248 & chr6:31664560 & $\mathrm{LST}_{1}{ }^{\mathrm{a}}$ & Exon & Yes \\
\hline
\end{tabular}

aLST1, leukocyte specific transcript 1 (also the 5' UTR of $L T B$ ).

CM enrolled in Dar es Salaam using WHO criteria as previously described [22] and asymptomatic malariaexposed, healthy control children from Mikocheni Primary school in the Kinondoni Municipality of the Dar 
es Salaam region. Written informed consent was obtained from all study subjects or their next of kin, parent or guardian. Studies were approved by the Ethics Committees of the National Institute of Health Research and Development (Ministry of Health, Jakarta, Indonesia), Menzies School of Health Research (Darwin, Australia), Queensland Institute of Medical Research (Brisbane, Australia), Muhimbili University of Health Sciences (Dar es Salaam, Tanzania), National Institute for Medical Research (Dar es Salaam, Tanzania), University of Utah Medical Center (Salt Lake City, USA) and Duke University Medical Center (Durham, USA).

\section{Sequencing the LTA gene}

The gene encoding LT $\alpha$, spanning a region of 5323 base pairs (bp) was sequenced in a subset of samples to check for the presence of novel SNPs. The locus was amplified in sections of approximately 500 bp by PCR and sequenced. Sequenced products were aligned against a published human $L T A$ sequence [23]. Identified SNPs were also checked on the NCBI website [24] for previous publication.

\section{SNP selection}

$T N F / L T A / L T B$ SNPs were included in this study based on reported functional changes (i.e. transcriptional or protein level) or on previous associations with malaria, other infectious diseases, ischaemic stroke, cerebral infarction, atherosclerosis or inflammation [9-12,14,18,25-43]. SNPs in the $T N F / L T A / L T B$ locus observed to be present in ethnic groups from Sulawesi, an island in the Indonesian archipelago [44], were also included. The final set of polymorphisms included as many functional and diseaseassociated SNPs as possible following primer design and testing. Tagging SNPs were selected based on reported frequencies in other populations. This SNP set has been described elsewhere [45]. All SNP sequences were obtained from the Chip Bioinformatics database [46] and verified in NCBI.

\section{Genotyping}

Assays were designed for thirty-five SNPs across the $T N F / L T A / L T B$ region in a multiplex using the Sequenom MassARRAY Assay Design software (version 3.0). SNPs were typed using iPLEX ${ }^{\text {ma }}$ chemistry and analyzed using a Sequenom MassARRAY Compact Mass Spectrometer (Sequenom Inc, San Diego, CA, USA). The $2.5 \mathrm{ml}$ PCR reactions were performed in standard 384-well plates using $10 \mathrm{ng}$ genomic DNA, 0.5 unit of Taq polymerase (HotStarTaq, Qiagen), $500 \mathrm{mmol}$ of each dNTP, and $100 \mathrm{nmol}$ of each PCR primer. Standard PCR thermal cycling conditions and post-PCR extension reactions were carried out as described previously [45]. The iPLEX reaction products were desalted and spotted on a
SpectroChip (Sequenom). Data were processed and analysed by MassARRAY Workstation (version 3.4) software (Sequenom). Single SNP genotyping specific for rs2071590 and rs1052248 was performed using TaqMan SNP Genotyping Assays according to the manufacturer's instructions (Applied Biosystems, Foster City, CA) by using the allelic discrimination on a Corbett RG-6000 (Corbett Life Sciences, Sydney, NSW, Australia) or an AB7900 machine (Applied Biosystems). Previously characterized genotypes for these SNPs were included as positive controls and run alongside samples with unknown genotype.

\section{Statistical analyses}

Based on our sample size (380 cases and 356 controls), $80 \%$ power was available to detect a disease allele with a relative risk of 1.5 at a disease frequency of 0.25 . Haploview version 3.32 (Whitehead Institute for Biomedical Research, USA; [47]) was used to perform all statistical tests relating to this SNP analysis [48]. Genotype frequencies of all SNPs were tested for departures from Hardy-Weinberg equilibrium in both cases and controls separately. In the Papuan study, 16 SNPs were found to be non-polymorphic (Table 1). Haplotype frequencies and linkage disequilibrium (LD) tests were also determined by Haploview version 3.32 [48] using the default method of Gabriel [49]. The association between single markers and haplotype blocks was performed by the Haploview programme. Generated $P$-values for SNPs spanning the $L T A / T N F / L T B$ locus were corrected for multiple testing of all the SNPs and haplotype blocks within the region tested through 10,000 permutations. A global P-value of $<0.05$ was considered statistically significant.

\section{Results}

\section{LTA/TNF locus is not associated with severe malaria}

In total, 380 SM cases (262 adults and 118 children) and 356 control individuals (305 adults and 51 children) were included in the genotyping study [21]. A subset of the samples was randomly chosen for sequencing of a 5,323 bp region spanning $L T A$, and this revealed no novel SNPs in the study population, and that all SNPs detected in the sequenced $L T A$ had previously been reported and, where possible, were included in the SNP set (Table 1). The SNP set consisted of 35 SNPs that spanned the $L T A / T N F / L T B$ locus on chromosome 6 (Figure 1 and Table 1). The majority of the samples were successfully genotyped for each of the SNPs with an average coverage of greater than $99 \%$. Of these, 16 SNPs were found to be non-polymorphic (Table 1). The minor allele frequencies of the remaining SNPs spanning the $L T A / T N F / L T B$ locus ranged from 0.001 to 0.44 in control subjects and from 0.001 to 0.49 in patients 


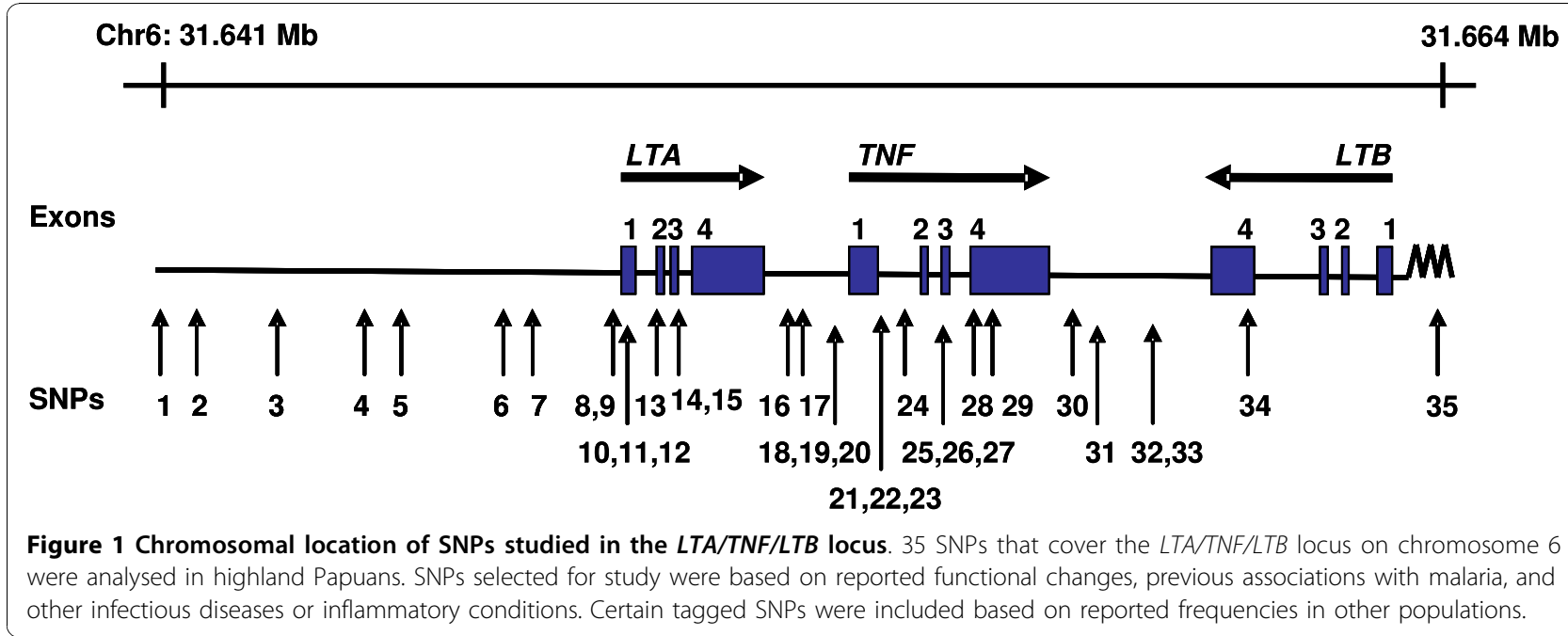

with SM. Two SNPs, rs2071590 and rs1052248, situated in the $L T A$ and $L T B$ promoter regions, respectively, showed some differences in allele frequencies between control subjects and SM patients $(P=0.034$ and $P=$ 0.007 , respectively). These differences were not observed once corrections were made for multiple testing (global $P>0.05$; Table 2). Analysis of haplotypes did not reveal any association between haplotype blocks and susceptibility to SM (Figure 2 and Table 3).

Next, the TNF/LTA/LTB locus was examined to establish whether it was associated with susceptibility to CM in either adults or children. Overall, there were no differences in allele frequencies between control subjects and CM patients (Table 4). Furthermore, neither age nor susceptibility to CM was associated with the TNF/ $L T A / L T B$ locus for either single SNPs or haplotype blocks (Tables 3 and 4; Figure 2). Given the association between the two SNPs situated in the LTA and LTB promoter regions and SM prior to correcting for multiple testing described above, the association of rs2071590 and rs1052248 in patients originating from and resident in a malaria-endemic region ( 245 healthy children $(\mathrm{HC})$ and 77 children with CM from Dar es Salaam, Tanzania) was also examined, but no association between these SNPs and CM was found. Taken together, there was no evidence for the TNF/LTA/LTB locus contributing to $\mathrm{SM}$ or $\mathrm{CM}$ in highland Papuans historically not exposed to malaria.

\section{Discussion}

Both genetic and serological data indicate roles for TNF and LT $\alpha$ in the pathogenesis of SM [6-14,50,51]. However, there was a lack of association between SNPs in the TNF/LTA/LTB and SM in a highland Papuan population. This lack of association remained following subsequent testing in disease subsets and in both children and adults. TNF polymorphisms have been associated with malaria transmission and SM, primarily in populations originating and living in malaria endemic areas [9-14]. A small number of studies have investigated the relationship between two LTA SNPs and malaria. LTA C+80A (rs2239704), a SNP that allows specific binding of the transcriptional repressor ABF-1 and, therefore, considered to be a low LT $\alpha$-producing allele, has been associated with lower P. falciparum parasitaemia in malaria-endemic Burkina Faso but was not associated with SM in a case-control study in The Gambia [40,51,52]. LTA A+252G (rs909253) has been reported to influence LT $\alpha$ production [53], but this SNP was not associated with SM in Sri Lanka [9]. More recently, rs2239704 and rs909253 were reported to not be associated with SM in a study of SM patients from The Gambia, Kenya and Malawi [20]. Both rs2239704 and rs909253 were included in the present study but not found to be associated with SM. A recent genome wide association study found that only rs2516486 at TNF was weakly associated with malaria severity, however the authors caution that the candidate SNPs examined in this study were poorly tagged by the $500 \mathrm{~K}$ array used [54].

LTA polymorphisms were of particular interest. In highland Papuans (a population without historical exposure to malaria), the minor allele for rs2239704 (Table 3) is the opposite allele to that observed in a study population from malaria-endemic Burkina Faso [51], suggesting that different pressures may have selected for different alleles in the two populations. Despite two SNPs situated in the $L T A$ and $L T B$ promoter regions (rs2071590 and rs1052248, respectively), having differences in allele frequencies between control subjects and SM patients, this was not significant after correction for multiple testing, nor was there a difference in the Tanzanian population 
Table 2 Association analysis of SNPs across the LTA/TNF/LTB gene locus genotyped in severe malaria cases and controls

\begin{tabular}{|c|c|c|c|c|c|c|c|c|c|}
\hline \multirow[t]{2}{*}{ dbSNP rs } & \multirow[t]{2}{*}{ Position } & \multirow[t]{2}{*}{ Gene } & \multirow[t]{2}{*}{ Role } & \multirow[t]{2}{*}{ Alleles } & \multicolumn{2}{|c|}{$\mathrm{MAF}^{\mathrm{a}}$} & \multirow{2}{*}{$\begin{array}{l}\mathrm{OR}^{\mathrm{b}} \\
(\mathrm{Cl})^{\mathrm{c}}\end{array}$} & \multirow{2}{*}{$\begin{array}{c}\text { Association }^{\mathrm{d}} \\
\chi^{2}\end{array}$} & \multirow[t]{2}{*}{$P$-value } \\
\hline & & & & & Controls & SM & & & \\
\hline rs2857602 & chr6:31641357 & LTA & Promoter & $G>A$ & 0.27 & 0.27 & $\begin{array}{l}1.02 \\
(0.81-1.28)\end{array}$ & 0.02 & 1.000 \\
\hline rs3131637 & chr6:31643053 & LTA & Promoter & $A>T$ & 0.27 & 0.27 & $\begin{array}{l}1.02 \\
(0.81-1.28)\end{array}$ & 0.02 & 1.000 \\
\hline rs2844484 & chr6:31644203 & LTA & Promoter & $A>G$ & 0.27 & 0.27 & $\begin{array}{l}1.03 \\
(0.81-1.29)\end{array}$ & 0.05 & 1.000 \\
\hline rs2844483 & chr6:31644775 & LTA & Promoter & $T>G$ & 0.27 & 0.27 & $\begin{array}{l}1.02 \\
(0.81-1.28)\end{array}$ & 0.02 & 1.000 \\
\hline rs2009658 & chr6:31646223 & LTA & Promoter & $C>G$ & 0.25 & 0.26 & $\begin{array}{l}1.05 \\
(0.83-1.33)\end{array}$ & 0.14 & 1.000 \\
\hline rs2844482 & chr6:31647746 & LTA & Promoter & $C>T$ & 0.25 & 0.26 & $\begin{array}{l}1.07 \\
(0.85-1.35)\end{array}$ & 0.30 & 1.000 \\
\hline rs2071590 & chr6:31647747 & LTA & Promoter & $A>G$ & 0.44 & 0.49 & $\begin{array}{l}1.25 \\
(1.02-1.54)\end{array}$ & 4.52 & 0.366 \\
\hline rs1800683 & chr6:31648050 & LTA & Promoter & $G>A$ & 0.02 & 0.01 & $\begin{array}{l}1.98 \\
(0.72-5.35)\end{array}$ & 1.82 & 0.979 \\
\hline rs2239704 & chr6:31648120 & LTA & Exon & $A>C$ & 0.27 & 0.27 & $\begin{array}{l}1.02 \\
(0.81-1.29)\end{array}$ & 0.03 & 1.000 \\
\hline rs909253 & chr6:31648292 & LTA & Intron (boundary) & $A>G$ & 0.02 & 0.01 & $\begin{array}{l}1.98 \\
(0.73-5.36)\end{array}$ & 1.84 & 0.978 \\
\hline rs2857713 & chr6:31648535 & LTA & Coding exon & $T>C$ & 0.25 & 0.26 & $\begin{array}{l}1.06 \\
(0.84-1.34)\end{array}$ & 0.23 & 1.000 \\
\hline rs1041981 & chr6:31648763 & LTA & Coding exon & $C>A$ & 0.02 & 0.01 & $\begin{array}{l}2.15 \\
(0.80-5.77)\end{array}$ & 2.44 & 0.814 \\
\hline rs1799964 & chr6:31650287 & LTA & $3^{\prime}$ UTR & $\mathrm{T}>\mathrm{C}$ & 0.25 & 0.27 & $\begin{array}{l}1.07 \\
(0.84-1.35)\end{array}$ & 0.30 & 1.000 \\
\hline rs1799724 & chr6:31650461 & LTA & $3^{\prime}$ UTR & $C>T$ & 0.43 & 0.39 & $\begin{array}{l}1.19 \\
(0.97-1.47)\end{array}$ & 2.76 & 0.755 \\
\hline rs1800610 & chr6:31651806 & TNF & Intron & $G>A$ & 0.42 & 0.39 & $\begin{array}{l}1.13 \\
(0.92-1.40)\end{array}$ & 1.37 & 0.992 \\
\hline rs3091257 & chr6:31654829 & TNF & $3^{\prime}$ UTR & $C>A$ & $<0.01$ & $<0.01$ & $\begin{array}{l}1.07 \\
(0.07-17.11)\end{array}$ & $<0.01$ & 1.000 \\
\hline rs769178 & chr6:31655493 & LTB & $3^{\prime}$ UTR & $C>A$ & 0.43 & 0.39 & $\begin{array}{l}1.20 \\
(0.97-1.49)\end{array}$ & 2.98 & 0.682 \\
\hline rs769177 & chr6:31655590 & LTB & $3^{\prime}$ UTR & $G>A$ & 0.04 & 0.05 & $\begin{array}{l}1.11 \\
(0.67-1.84)\end{array}$ & 0.15 & 1.000 \\
\hline rs1052248 & chr6:31664560 & LST1 & Exon & $A>T$ & 0.42 & 0.49 & $\begin{array}{l}1.33 \\
(1.08-1.63)\end{array}$ & 7.22 & 0.098 \\
\hline
\end{tabular}

${ }^{\mathrm{a}}$ Minor allele frequency.

${ }^{\mathrm{b}}$ Odds ratio.

c95\% confidence interval.

${ }^{\mathrm{d}}$ Association $\chi^{2}$ with severe malaria.

studied. Thus, our data provide no evidence for an involvement of the $L T A / T N F / L T B$ locus in SM susceptibility in highland Papuans, and suggest that if the genes encoded by this locus are involved in SM pathogenesis then molecules that regulate the production and/or bioavailablity may influence disease outcome. Interestingly, an association between susceptibility to SM and a SNP in the LT $\alpha$-related gene encoding galectin-2 (LGALS2) was recently identified. The particular SNP in LGALS2 is thought to regulate the trafficking of LT $\alpha$ out of cells [55]. Strikingly, the association between
LGALS2 and SM was found to be present in highland Papuan children, but not adults [21]. A further consideration in future studies should be the effects of other genes with important immunological functions in the region surrounding the TNF locus that could contribute to the development of severe malaria. The potential importance of such genes was highlighted in a recent study showing that SNPs in HLA-B associated transcript 2 (BAT2) in the MHC III region were associated with severe malaria susceptibility, while $T N F$ and LTA SNPs were not [52]. 


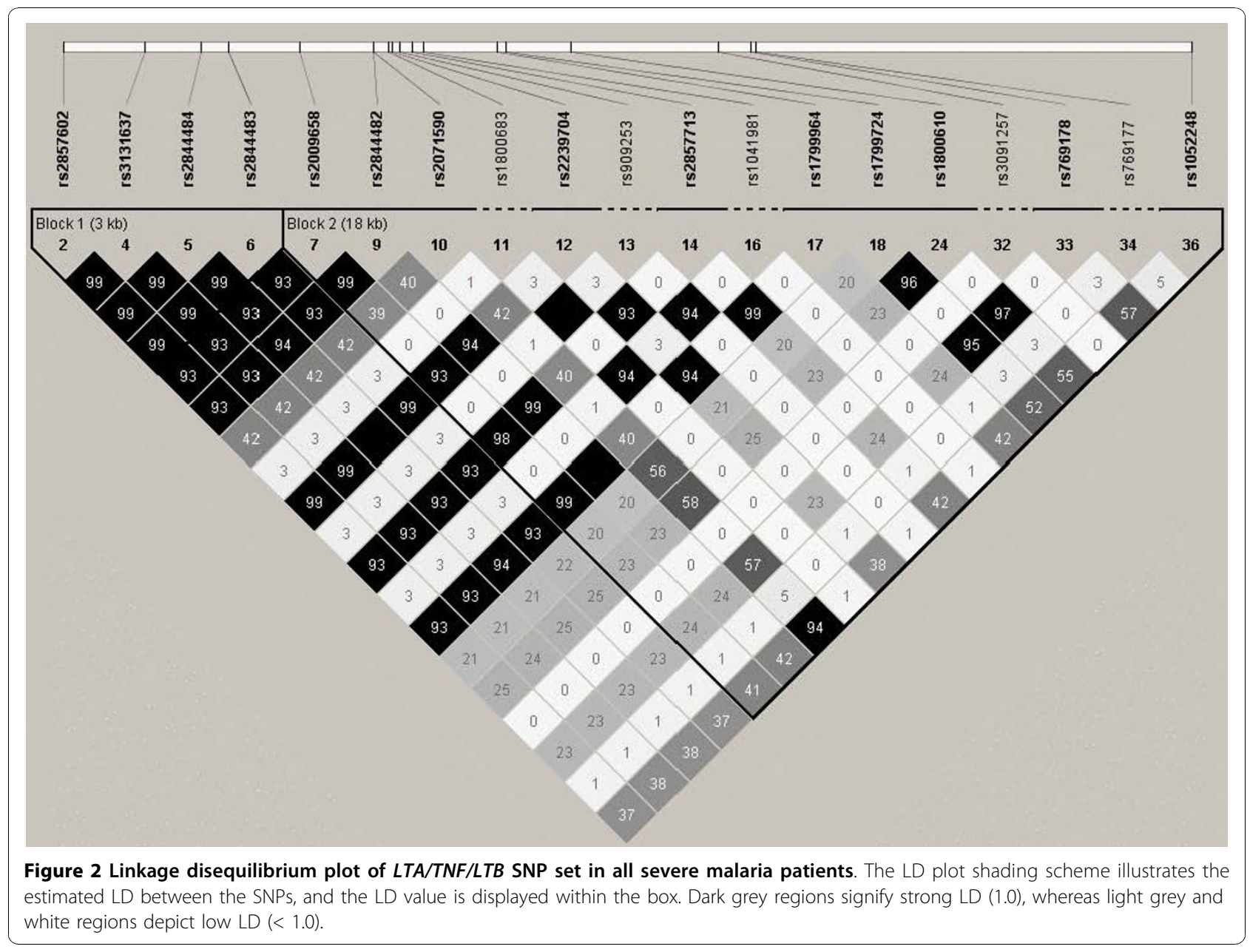

\section{Conclusion}

It is clear that large, highly powered studies will be necessary to identify causal variants in genes that contribute to SM disease outcome. However, as discussed above, it is likely that different populations have had different selective pressures placed upon them, resulting in a number of susceptibility alleles across different populations. Hence, deep sequencing studies in the TNF/

Table 3 Common haplotype blocks and their association with severe malaria

\begin{tabular}{lccc}
\hline Haplotype & $\begin{array}{c}\text { Frequency } \\
\text { (control) }\end{array}$ & $\mathbf{c}^{\mathbf{2}}$ & $\boldsymbol{P}$-value \\
\hline Block 1: & 0.73 & 0.01 & 1.000 \\
GAAT & 0.27 & 0.01 & 1.000 \\
ATGG & & & \\
Block 2: & 0.42 & 1.38 & 0.992 \\
CCAATTAAA & 0.24 & 0.56 & 1.000 \\
GTGCCCCGCT & 0.17 & 6.63 & 0.133 \\
CCGATTCGCT & 0.14 & 1.64 & 0.984 \\
CCAATTCGCA & & & \\
\hline
\end{tabular}

$L T A / L T B$ locus of different populations may be warranted and required to identify causal variants in these genes responsible for susceptibility to SM syndromes.

\section{List of abbreviations}

SM: severe malaria; TNF: tumour necrosis factor; LT: lymphotoxin; CM: cerebral malaria; SNP: single nucleotide polymorphism; SMA: severe malaria anaemia; ARDS: acute respiratory distress syndrome; bp: base pair; LD: linkage disequilibrium.

\section{Competing interests}

The authors declare that they have no competing interests.

\section{Authors' contributions}

LMR performed experiments, analysed data and drafted the manuscript, EK, DAL, ET, EDM, TH, KP, ZZZ, FLR, YZ, KMS, LL, FHA, AH, ACS, TW and ES collected and processed samples, and performed experiments, DLG, MRH RNP, JBW, GWM, NMA and CRE designed experiments analysed data and wrote the manuscript. All authors read and approved the final manuscript.

\section{Acknowledgements}

We thank Michael Good for his critical review of the manuscript and helpful comments. We thank Ferryanto Chalfein, Prayoga, Daud Rumere, Roesmini, Yoshi Elvi for technical and logistical assistance; Mitra Masyarakat Hospital staff for clinical support; Mauritz Okeseray, Jeanne Rini, Paulus Sugiarto and Lembaga Pengembangan Masyarakat Amungme Kamoro for support in Timika; and Mushtaq Hassanali, Dennis Manyenga (deceased), Gustav Moyo, 
Table 4 Lack of association between LTA/TNF/LTB SNPs and severe malaria subgroups when compared with adult and childhood controls in the Papuan population

\begin{tabular}{|c|c|c|c|c|c|c|c|c|c|c|}
\hline \multirow[t]{2}{*}{ dbSNP rs } & \multicolumn{2}{|c|}{$\frac{\text { All CM }}{(106)^{a}}$} & \multicolumn{2}{|c|}{$\frac{\text { Adult SM }}{(262)}$} & \multicolumn{2}{|c|}{$\frac{\text { Adult CM }}{(85)}$} & \multicolumn{2}{|c|}{ Childhood SM(118) } & \multicolumn{2}{|c|}{ Childhood CM(21) } \\
\hline & $\mathrm{MAF}^{\mathrm{b}}$ & $P$-value & MAF & $P$-value & MAF & $P$-value & MAF & $P$-value & MAF & $P$-value \\
\hline rs2857602 & 0.28 & 1.000 & 0.27 & 1.000 & 0.27 & 1.000 & 0.28 & 0.999 & 0.26 & 1.000 \\
\hline rs3131637 & 0.28 & 1.000 & 0.27 & 1.000 & 0.27 & 1.000 & 0.28 & 0.999 & 0.26 & 1.000 \\
\hline rs2844484 & 0.28 & 1.000 & 0.27 & 1.000 & 0.27 & 1.000 & 0.28 & 0.999 & 0.26 & 1.000 \\
\hline rs2844483 & 0.28 & 1.000 & 0.27 & 1.000 & 0.27 & 1.000 & 0.28 & 0.999 & 0.26 & 1.000 \\
\hline rs2009658 & 0.25 & 1.000 & 0.26 & 1.000 & 0.26 & 1.000 & 0.26 & 0.951 & 0.22 & 0.999 \\
\hline rs2844482 & 0.27 & 1.000 & 0.26 & 1.000 & 0.26 & 1.000 & 0.26 & 0.957 & 0.22 & 0.999 \\
\hline rs2071590 & 0.51 & 0.841 & 0.46 & 0.895 & 0.45 & 0.963 & 0.47 & 0.631 & 0.44 & 0.950 \\
\hline rs1800683 & 0.01 & 1.000 & 0.01 & 1.000 & 0.01 & 1.000 & 0.02 & 0.488 & 0.04 & 1.000 \\
\hline rs2239704 & 0.28 & 1.000 & 0.27 & 1.000 & 0.27 & 1.000 & 0.28 & 0.999 & 0.26 & 1.000 \\
\hline rs909253 & 0.01 & 1.000 & 0.01 & 1.000 & 0.01 & 1.000 & 0.02 & 0.488 & 0.04 & 1.000 \\
\hline rs2857713 & 0.27 & 1.000 & 0.26 & 1.000 & 0.26 & 1.000 & 0.26 & 0.983 & 0.23 & 1.000 \\
\hline rs1041981 & 0.01 & 1.000 & 0.01 & 0.999 & 0.01 & 1.000 & 0.02 & 0.488 & 0.04 & 1.000 \\
\hline rs1799964 & 0.27 & 1.000 & 0.26 & 1.000 & 0.26 & 1.000 & 0.26 & 0.951 & 0.22 & 0.999 \\
\hline rs1799724 & 0.36 & 0.597 & 0.41 & 0.992 & 0.41 & 0.869 & 0.41 & 0.744 & 0.45 & 0.992 \\
\hline rs1800610 & 0.36 & 0.902 & 0.40 & 1.000 & 0.40 & 0.945 & 0.41 & 0.828 & 0.44 & 0.996 \\
\hline rs3091257 & - & - & - & - & - & - & - & - & - & - \\
\hline rs769178 & 0.36 & 0.581 & 0.41 & 0.992 & 0.41 & 0.851 & 0.41 & 0.83 & 0.44 & 0.996 \\
\hline rs769177 & 0.06 & 0.983 & 0.04 & 1.000 & 0.04 & 1.000 & 0.05 & 1.00 & 0.06 & 0.995 \\
\hline rs1052248 & 0.50 & 0.490 & 0.45 & 0.543 & 0.44 & 0.878 & 0.46 & 0.26 & 0.40 & 0.884 \\
\hline
\end{tabular}

${ }^{\mathrm{a}}$ Number in each group.

${ }^{\mathrm{b}} \mathrm{MAF}$ - minor allele frequency in cases.

Stella Stanslaus, Bernard John, Sofia Mbangukura and Ann Shumbusho for clinical, technical and logistical assistance in Dar es Salaam. We also thank Leanne Morrison and Dennis Moss for provision of EBV-transformed cell lines.

This work was supported by grants from the National Institutes of Health (Al55982 and Al041764), Australian NHMRC Programme Grants (290208 and 496600), the US V. A. Research Service, Australian Postgraduate Award to LMR, Australian NHMRC Fellowships to CRE, NMA and GM, Wellcome Trust Career Development Award to RNP and the Tudor Foundation.

\section{Author details}

'Queensland Institute of Medical Research and Australian Centre for Vaccine Development, 300 Herston Road, Herston, QLD 4006, Australia. ${ }^{2}$ The University of Queensland, School of Population Health, Herston Road, Herston, QLD 4006, Australia. ${ }^{3}$ National Institute of Health Research and Development-Menzies School of Health Research Malaria Research Programme, and District Ministry of Health, Timika, Papua, Indonesia. ${ }^{4}$ National Institute of Health Research and Development, Jakarta, Indonesia. ${ }^{5}$ Department of Paediatrics, Herbert Kairuki Memorial University, Dar es Salaam, Tanzania. ${ }^{6}$ International Health Division, Menzies School of Health Research and Charles Darwin University, Darwin, NT, Australia. ${ }^{7}$ Divisions of Infectious Diseases and Endocrinology, University of Utah and VA Medical Centers, Utah, USA. ${ }^{8}$ Centre for Vaccinology \& Tropical Medicine, Nuffield Department of Clinical Medicine, Churchill Hospital, Oxford, UK. ${ }^{9}$ Division of Medicine, Royal Darwin Hospital, Darwin, NT, Australia. ${ }^{10}$ Division of Hematology-Oncology, Duke and VA Medical Centers, Durham, NC, USA.

Received: 7 July 2010 Accepted: 29 October 2010 Published: 29 October 2010

\section{References}

1. WHO: Severe falciparum malaria. World Health Organization, Communicable Diseases Cluster. Trans R Soc Trop Med Hyg 2000, 94(Suppl 1):S1-90.

2. WHO: World Malaria Report 2008. Program WGM. Geneva 2008.
3. Rich SM, Licht MC, Hudson RR, Ayala FJ: Malaria's Eve: evidence of a recent population bottleneck throughout the world populations of Plasmodium falciparum. Proc Natl Acad Sci USA 1998, 95:4425-4430.

4. Kun JF, Mordmuller B, Perkins DJ, May J, Mercereau-Puijalon O, Alpers M, Weinberg JB, Kremsner PG: Nitric oxide synthase 2(Lambarene) (G-954C), increased nitric oxide production, and protection against malaria. J Infect Dis 2001, 184:330-336.

5. Grau GE, Fajardo LF, Piguet PF, Allet B, Lambert PH, Vassalli P: Tumor necrosis factor (cachectin) as an essential mediator in murine cerebral malaria. Science 1987, 237:1210-1212.

6. Grau GE, Piguet PF, Vassalli P, Lambert PH: Tumor-necrosis factor and other cytokines in cerebral malaria: experimental and clinical data. Immunol Rev 1989, 112:49-70.

7. Kern P, Hemmer CJ, Van Damme J, Gruss HJ, Dietrich M: Elevated tumor necrosis factor alpha and interleukin- 6 serum levels as markers for complicated Plasmodium falciparum malaria. Am J Med 1989, 87:139-143.

8. Kwiatkowski D: Tumour necrosis factor, fever and fatality in falciparum malaria. Immunol Lett 1990, 25:213-216.

9. Wattavidanage J, Carter R, Perera KL, Munasingha A, Bandara S, McGuinness D, Wickramasinghe AR, Alles HK, Mendis KN, Premawansa S: TNFalpha*2 marks high risk of severe disease during Plasmodium falciparum malaria and other infections in Sri Lankans. Clin Exp Immunol 1999, 115:350-355

10. Aidoo M, McElroy PD, Kolczak MS, Terlouw DJ, ter Kuile FO, Nahlen B, Lal AA, Udhayakumar $V$ : Tumor necrosis factor-alpha promoter variant 2 (TNF2) is associated with pre-term delivery, infant mortality, and malaria morbidity in western Kenya: Asembo Bay Cohort Project IX. Genet Epidemiol 2001, 21:201-211.

11. Ubalee R, Suzuki F, Kikuchi M, Tasanor O, Wattanagoon $Y$, Ruangweerayut $R$, Na-Bangchang K, Karbwang J, Kimura A, Itoh K, Kanda T, Hirayama K: Strong association of a tumor necrosis factor-alpha promoter allele with cerebral malaria in Myanmar. Tissue Antigens 2001, 58:407-410.

12. Hananantachai H, Patarapotikul J, Ohashi J, Naka I, Krudsood S, Looareesuwan S, Tokunaga K: Significant association between TNF-alpha (TNF) promoter allele $(-1031 \mathrm{C},-863 \mathrm{C}$, and $-857 \mathrm{C})$ and cerebral malaria in Thailand. Tissue Antigens 2007, 69:277-280. 
13. Sinha S: TNF-alpha alleles and susceptibility to cerebral malaria. Natl Med J India 1995, 8:70-72.

14. McGuire W, Hill AV, Allsopp CE, Greenwood BM, Kwiatkowski D: Variation in the TNF-alpha promoter region associated with susceptibility to cerebral malaria. Nature 1994, 371:508-510.

15. Wilson AG, Symons JA, McDowell TL, McDevitt HO, Duff GW: Effects of a polymorphism in the human tumor necrosis factor alpha promoter on transcriptional activation. Proc Natl Acad Sci USA 1997, 94:3195-3199.

16. Brinkman BM, Zuijdeest D, Kaijzel EL, Breedveld FC, Verweij CL: Relevance of the tumor necrosis factor alpha (TNF alpha) -308 promoter polymorphism in TNF alpha gene regulation. J Inflamm 1995, 46:32-41.

17. Ackerman $H C$, Ribas $G$, Jallow M, Mott R, Neville M, Sisay-Joof F, Pinder $M$, Campbell RD, Kwiatkowski DP: Complex haplotypic structure of the central MHC region flanking TNF in a West African population. Genes Immun 2003, 4:476-486.

18. Knight JC, Keating BJ, Rockett KA, Kwiatkowski DP: In vivo characterization of regulatory polymorphisms by allele-specific quantification of RNA polymerase loading. Nat Genet 2003, 33:469-475.

19. Engwerda CR, Mynott TL, Sawhney S, DeSouza JB, Bickle QD, Kaye PM: Locally up-regulated lymphotoxin alpha, not systemic tumor necrosis factor alpha, is the principle mediator of murine cerebral malaria. J Exp Med 2002, 195:1371-1377.

20. Clark TG, Diakite M, Auburn S, Campino S, Fry AE, Green A, Richardson A, Small K, Teo YY, Wilson J, Jallow M, Sisay-Joof F, Pinder M, Griffiths MJ, Peshu M, Williams TN, Marsh K, Molyneux ME, Taylor TE, Rockett KA, Kwiatkowski DP: Tumor necrosis factor and lymphotoxin-alpha polymorphisms and severe malaria in African populations. J Infect Dis 2009, 199:569-575.

21. Randall LM, Kenangalem E, Lampah DA, Tjitra E, Mwaikambo ED, Handojo T, Piera KA, Zhao ZZ, de Labastida Rivera F, Zhou Y, McSweeney KM, Le L, Amante FH, Haque A, Stanley AC, Woodberry T, Salwati E, Granger DL, Hobbs MR, Price RN, Weinberg JB, Montgomery GW, Anstey NM, Engwerda CR: Age-related susceptibility to severe malaria associated with galectin-2 in highland Papuans. J Infect Dis 2010, 202:117-124.

22. Anstey NM, Weinberg JB, Hassanali MY, Mwaikambo ED, Manyenga D, Misukonis MA, Arnelle DR, Hollis D, McDonald Ml, Granger DL: Nitric oxide in Tanzanian children with malaria: inverse relationship between malaria severity and nitric oxide production/nitric oxide synthase type 2 expression. J Exp Med 1996, 184:557-567.

23. Ensembl. [http://www.ensembl.org].

24. National Center for Biotechnology Information. [http://www.ncbi.nlm.nih. gov/SNP].

25. Um JY, An NH, Kim HM: TNF-alpha and TNF-beta gene polymorphisms in cerebral infarction. J Mol Neurosci 2003, 21:167-171.

26. Lee BC, Ahn SY, Doo HK, Yim SV, Lee HJ, Jin SY, Hong SJ, Lee SH, Kim SD, Seo JC, Leem KH, Chung JH: Susceptibility for ischemic stroke in Korean population is associated with polymorphisms of the interleukin-1 receptor antagonist and tumor necrosis factor-alpha genes, but not the interleukin-1 beta gene. Neurosci Lett 2004, 357:33-36.

27. Cabrera M, Shaw MA, Sharples C, Williams H, Castes M, Convit J, Blackwell JM: Polymorphism in tumor necrosis factor genes associated with mucocutaneous leishmaniasis. J Exp Med 1995, 182:1259-1264.

28. Albuquerque RV, Hayden CM, Palmer $\amalg$, Laing IA, Rye PJ, Gibson NA, Burton PR, Goldblatt J, Lesouef PN: Association of polymorphisms within the tumour necrosis factor (TNF) genes and childhood asthma. Clin Exp Allergy 1998, 28:578-584

29. Trabetti E, Patuzzo C, Malerba G, Galavotti R, Martinati LC, Boner AL, Pignatti PF: Association of a lymphotoxin alpha gene polymorphism and atopy in Italian families. J Med Genet 1999, 36:323-325.

30. Moffatt MF, James A, Ryan G, Musk AW, Cookson WO: Extended tumour necrosis factor/HLA-DR haplotypes and asthma in an Australian population sample. Thorax 1999, 54:757-761.

31. Grutters JC, Sato H, Pantelidis P, Lagan AL, McGrath DS, Lammers JW, van den Bosch JM, Wells AU, du Bois RM, Welsh KI: Increased frequency of the uncommon tumor necrosis factor -857T allele in British and Dutch patients with sarcoidosis. Am J Respir Crit Care Med 2002, 165:1119-1124.

32. Swider C, Schnittger L, Bogunia-Kubik K, Gerdes J, Flad H, Lange A, Seitzer U: TNF-alpha and HLA-DR genotyping as potential prognostic markers in pulmonary sarcoidosis. Eur Cytokine Netw 1999, 10:143-146.

33. Bouqbis L, Akhayat O, Garchon HJ, Calafell F, Izaabel H: TNFA-TNFB haplotypes modify susceptibility to type I diabetes mellitus independently of HLA class II in a Moroccan population. Tissue Antigens 2003, 61:72-79.

34. Lio D, Caruso C, Di Stefano R, Colonna Romano G, Ferraro D, Scola L, Crivello A, Licata A, Valenza LM, Candore G, Craxi A, Almasio PL: IL-10 and TNF-alpha polymorphisms and the recovery from HCV infection. Hum Immunol 2003, 64:674-680.

35. Niro GA, Fontana R, Gioffreda D, Valvano MR, Lacobellis A, Facciorusso D, Andriulli A: Tumor necrosis factor gene polymorphisms and clearance or progression of hepatitis B virus infection. Liver Int 2005, 25:1175-1181.

36. Knight JC, Udalova I, Hill AV, Greenwood BM, Peshu N, Marsh K, Kwiatkowski D: A polymorphism that affects OCT-1 binding to the TNF promoter region is associated with severe malaria. Nat Genet 1999, 22:145-150.

37. Ozaki K, Ohnishi Y, lida A, Sekine A, Yamada R, Tsunoda T, Sato H, Sato H, Hori M, Nakamura Y, Tanaka T: Functional SNPs in the lymphotoxin-alpha gene that are associated with susceptibility to myocardial infarction. Nat Genet 2002, 32:650-654.

38. Satoh T, Pandey JP, Okazaki Y, Yasuoka H, Kawakami Y, Ikeda Y, Kuwana M: Single nucleotide polymorphisms of the inflammatory cytokine genes in adults with chronic immune thrombocytopenic purpura. Br I Haematol 2004, 124:796-801.

39. Suzuki G, Izumi S, Hakoda M, Takahashi N: LTA 252G allele containing haplotype block is associated with high serum C-reactive protein levels. Atherosclerosis 2004, 176:91-94.

40. Knight JC, Keating BJ, Kwiatkowski DP: Allele-specific repression of lymphotoxin-alpha by activated B cell factor-1. Nat Genet 2004, 36:394-399.

41. Laxton R, Pearce E, Kyriakou T, Ye S: Association of the lymphotoxin-alpha gene Thr26Asn polymorphism with severity of coronary atherosclerosis. Genes Immun 2005, 6:539-541.

42. Liu Y, Herrington D, Burdon KP, Langefeld CD, Rich SS, Bowden DW Freedman BI, Wagenknecht LE: A functional polymorphism in the lymphotoxin-alpha gene is associated with carotid artery wall thickness: the Diabetes Heart Study. Eur J Cardiovasc Prev Rehabil 2006, 13:655-657.

43. Niwa Y, Hirose K, Matsuo K, Tajima K, Ikoma Y, Nakanishi T, Nawa A, Kuzuya K, Tamakoshi A, Hamajima N: Lymphotoxin-alpha polymorphism and the risk of cervical cancer in Japanese subjects. Cancer Lett 2005, 218:63-68.

44. Lamsis F, Flannery GR, White NG, Muratore R, Kaelan C, Mitchell RJ: Alleles and haplotypes of tumor necrosis factor (TNF) alpha and beta genes in three ethnic populations of Sulawesi Indonesia. Hum Biol 2002, 74:381-396.

45. Zhao ZZ, Nyholt DR, Le L, Thomas S, Engwerda C, Randall L, Treloar SA, Montgomery GW: Genetic variation in tumour necrosis factor and lymphotoxin is not associated with endometriosis in an Australian sample. Hum Reprod 2007, 22:2389-2397.

46. CHIP Bioinformatics Tools. [http://snpper.chip.org]

47. Haploview. [http://www.broad.mit.edu/mpg/haploview]

48. Barrett JC, Fry B, Maller J, Daly MJ: Haploview: analysis and visualization of LD and haplotype maps. Bioinformatics 2005, 21:263-265.

49. Gabriel SB, Schaffner SF, Nguyen H, Moore JM, Roy J, Blumenstiel B, Higgins J, DeFelice M, Lochner A, Faggart M, Liu-Cordero SN, Rotimi C, Adeyemo A, Cooper R, Ward R, Lander ES, Daly MJ, Altshuler D: The structure of haplotype blocks in the human genome. Science 2002, 296:2225-2229.

50. Clark IA, Gray KM, Rockett EJ, Cowden WB, Rockett KA, Ferrante A, Aggarwal BB: Increased lymphotoxin in human malarial serum, and the ability of this cytokine to increase plasma interleukin- 6 and cause hypoglycaemia in mice: implications for malarial pathology. Trans $R$ Soc Trop Med Hyg 1992, 86:602-607.

51. Barbier M, Delahaye NF, Fumoux F, Rihet P: Family-based association of a low producing lymphotoxin-alpha allele with reduced Plasmodium falciparum parasitemia. Microbes Infect 2008, 10:673-679.

52. Diakite M, Clark TG, Auburn S, Campino S, Fry AE, Green A, Morris AP, Richardson A, Jallow M, Sisay-Joof F, Pinder M, Kwiatkowski DP, Rockett KA: A genetic association study in the Gambia using tagging polymorphisms in the major histocompatibility complex class III region implicates a HLA-B associated transcript 2 polymorphism in severe malaria susceptibility. Hum Genet 2009, 125:105-109.

53. Messer G, Spengler U, Jung MC, Honold G, Blomer K, Pape GR, Riethmuller $\mathrm{G}$, Weiss EH: Polymorphic structure of the tumor necrosis 
factor (TNF) locus: an Ncol polymorphism in the first intron of the human TNF-beta gene correlates with a variant amino acid in position 26 and a reduced level of TNF-beta production. J Exp Med 1991, 173:209-219.

54. Jallow M, Teo YY, Small KS, Rockett KA, Deloukas P, Clark TG, Kivinen K, Bojang KA, Conway DJ, Pinder M, Sirugo G, Sisay-Joof F, Usen S, Auburn S, Bumpstead SJ, Campino S, Coffey A, Dunham A, Fry AE, Green A,

Gwilliam R, Hunt SE, Inouye M, Jeffreys AE, Mendy A, Palotie A, Potter S, Ragoussis J, Rogers J, Rowlands K, Somaskantharajah E, Whittaker $P$, Widden C, Donnelly P, Howie B, Marchini J, Morris A, Sanjoaquin M, Achidi EA, Agbenyega T, Allen A, Amodu O, Corran P, Djimde A, Dolo A, Doumbo OK, Drakeley C, Dunstan S, Evans J, Farrar J, Fernando D, Hien TT, Horstmann RD, Ibrahim M, Karunaweera N, Kokwaro G, Koram KA, Lemnge M, Makani J, Marsh K, Michon P, Modiano D, Molyneux ME, Mueller I, Parker M, Peshu N, Plowe CV, Puijalon O, Reeder J, Reyburn H, Riley EM, Sakuntabhai A, Singhasivanon P, Sirima S, Tall A, Taylor TE, Thera M, Troye-Blomberg M, Williams TN, Wilson M, Kwiatkowski DP: Genome-wide and fine-resolution association analysis of malaria in West Africa. Nat Genet 2009.

55. Ozaki K, Inoue K, Sato H, lida A, Ohnishi Y, Sekine A, Sato H, Odashiro K, Nobuyoshi M, Hori M, Nakamura Y, Tanaka T: Functional variation in LGALS2 confers risk of myocardial infarction and regulates lymphotoxinalpha secretion in vitro. Nature 2004, 429:72-75.

doi:10.1186/1475-2875-9-302

Cite this article as: Randall et al: A study of the TNF/LTA/LTB locus and susceptibility to severe malaria in highland papuan children and adults. Malaria Journal 2010 9:302.

\section{Submit your next manuscript to BioMed Central and take full advantage of:}

- Convenient online submission

- Thorough peer review

- No space constraints or color figure charges

- Immediate publication on acceptance

- Inclusion in PubMed, CAS, Scopus and Google Scholar

- Research which is freely available for redistribution

Submit your manuscript at www.biomedcentral.com/submit 